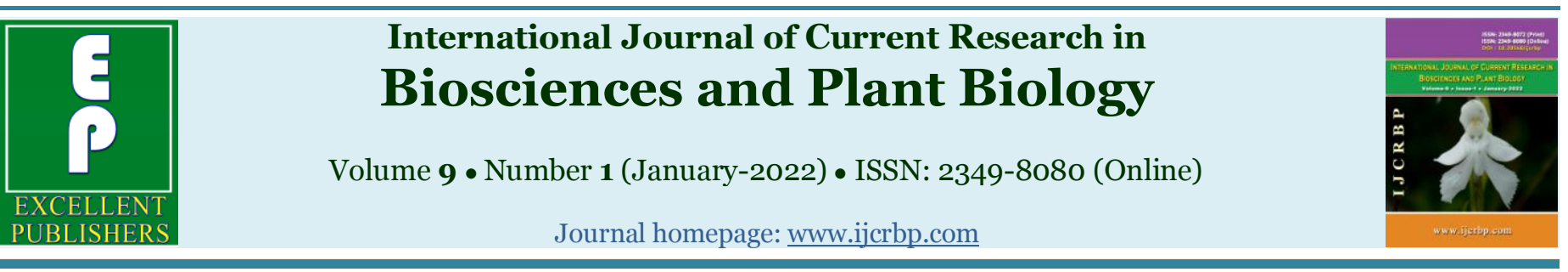

Original Research Article

doi: https://doi.org/10.20546/ijcrbp.2022.901.005

\title{
Lectotypification of Andropogon compressus Hook.f. basionym of Bothriochloa compressa (Hook.f.) Henrard (Andropogoneae: Poaceae)
}

\author{
Pooja Mane ${ }^{1}$, Chandrakant Salunkhe ${ }^{1} *$, Girish Potdar ${ }^{2}$ \\ ${ }^{I}$ Department of Botany, Krishna Mahavidyalaya, Rethare Bk., Maharashtra-415 108, India \\ ${ }^{2}$ Department of Botany, Yashwantrao Chavan College of Science, Karad, Maharashtra - 415124, India \\ *Corresponding author; e-mail: chandrakantsalunkhe62@gmail.com
}

\begin{tabular}{ll}
\hline Article Info & Abstract \\
\hline Keywords: & The lectotype is designated for the name Andropogon compressus Hook.f. \\
Bothriochloa & \\
India & \\
Lectotype & \\
Poaceae &
\end{tabular}

- Received: 19 November 2021 • Revised: 14 December 2021 • Accepted: 21 December 2021 • Published Online: 6 January 2022

Introduction

The genus Bothriochloa Kuntze (762: 1891) (Andropogoneae: Poaceae) is widely distributed throughout the world and represented by 38 species (POWO, 2021). In India, the genus is represented by 13 species, of which six species are endemic (Prasanna et al., 2020; Kellogg et al., 2020). While revising the genus Bothriochloa Kuntze for India, we found that the name Andropogon compressus Hook.f. (1897: 172) basionym of Bothriochloa compressa (Hook.f.) Henrard (1940:456) not been typified so far.

\section{Typification}

Bothriochloa compressa (Hook.f.) Henrard (1940: 456) = Andropogon compressus Hook.f. (1897: 172).
Type

INDIA, Deccan, December 1891, Lisboa No. 6 (K001057429 image! Lectotype designated here).

Notes

J.D. Hooker (1897) described Andropogon compressus based on Mrs. Lisboa's collection No. 6 (A. odoratus) and Woodrow's collections. In the protologue he cited "The Deccan, Lisboa (No. 6 A. odoratus), Woodrow".

While describing the species J.D. Hooker mentioned in the protologue "sent by Mrs. Lisboa as A. odoratus, but apparently very different from the description of that plant and from the specimens received in the strongly compressed and acutely keeled sheaths, broad leaves, and inflorescence". 


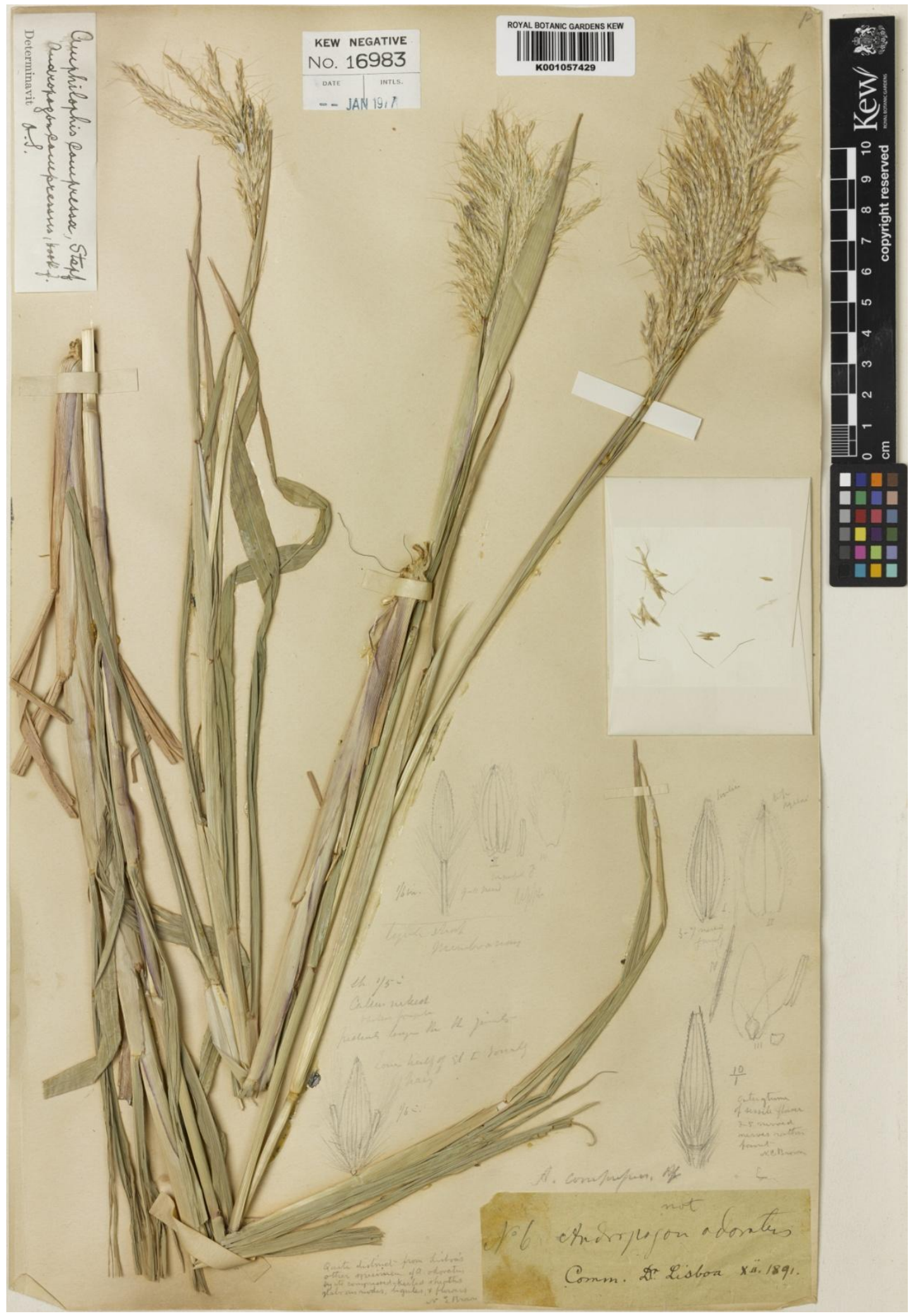

Fig. 1: Lectotype of Bothriochloa compressa (K001057429). Available at http://specimens.kew.org/herbarium/K001057429. (C) Copyright Board of Trustees of the Royal Botanic Gardens, Kew. 
From taxonomic literature (Stafleu and Cowan, 1981) we came to know J.C. Lisoba's major collection are housed at BLATT, DD, and K. Likewise, G.M. Woodrow's collection are housed at (BSI, DBN, DS, E, and $\mathrm{K}$ )

We could trace one collection of each collector at $\mathrm{K}$ (Woodrow collection at $1880 \mathrm{~K} 000245659$ image!), and Mrs. Lisboa's collection at 1891 K001057429 image!).

Both the specimens are well agreeing to the protologue of Andropogon compressus Hook.f. Apart from these two collections we could not find any other collection in any herbaria.

Since, Mrs. Lisboa's specimen is a complete specimen along with roots, strongly keeled and compressed sheath, broad leaves, and inflorescence and the herbarium specimen also bears illustrations of sessile and pedicelled spikelets with its description. Therefore, we are designating here as lectotype following the ICN Art. 9.3 (Turland et al., 2018).

\section{Conflict of interest statement}

Authors declare that they have no conflict of interest.

\section{Acknowledgement}

This study has been financially supported by Chhatrapati Shahu Maharaj Research, Training and Human Development Institute (SARTHI), Pune (CINU74999PN2018NPL177394). The authors are thankful to the authorities at BSA, BSJO, CAL and MH herbaria to consult the specimens in person, and herbaria A, E, $\mathrm{K}$, and NY for making the specimens available online. We also thank the authorities of Krishna Mahavidyalaya, Rethare $\mathrm{Bk}$ and Principal of
Yashwantrao Chavan College of Science, Karad for providing the research facilities and workplace. We are also thankful to Dr. Gopal Krishna, Botanical Survey of India, Kolkata for his valuable guidance.

\section{References}

Henrard, J. T., 1940. Notes on the nomenclature of some grasses. Blumea, 3(3): 456.

Hooker, J. D. 1897. Flora of British India. Vol. 7. London: L. Reeve \& Co.

Kellogg, E. A., Abbott, J. R., Kamaljit, B. K. S., Gandhi, K. N., Kailash, B. R., Ganeshaiah, K. N., Shrestha, U. B., Raven, P., 2020; Checklist of the grasses of India. PhytoKeys, 163: 1-560.

Kuntze, C. E. O., 1891. Revisio Generum Plantarum, Vol. 2. Arthur Felix, Leipzig. p.762.

POWO, 2021. Plants of the World Online, Facilitated by the Royal Botanic Gardens, Kew. Available at: http://www.plantsoftheworldonline.org/ (Accessed on 30.00.2021).

Prasanna, P. V., Chowdhury, S. D., Arumugam, S., Vivek, C. P., Chorghe, A., Sitrishna, K., Prasad, K., 2020. Poaceae (Gramineae). In: Flowering Plants of India-An Annotated Checklist (Monocotyledons), (Eds.: Mao, A. A., Dash, S. S.), Botanical Survey of India, Kolkata. p.327.

Stafleu, F. A., Cowan, R. S., 1981. Taxonomic Literature, Vol. 3. Bohn, Scheltema and Holkema,Utrecht, p.118.

Turland, N. J., Wiersema, J. H., Barrie, F. R., Greuter, W., Hawksworth, D. L., Herendeen, P. S., Knapp, S., Kusber, W. H., Li, D. Z., Marhold, K., May, T. W., McNeill, J., Monro, A. M., Prado, J., Price, M. J., Smith, G. F., 2017. International Code of Nomenclature for Algae, Fungi, and Plants (Shenzhen Code): Adopted by the Nineteenth International Botanical Congress, Shenzhen, China. p.9.

\footnotetext{
How to cite this article:

Mane, P., Salunkhe, C., Potdar, G., 2022. Lectotypification of Andropogon compressus Hook.f. basionym of Bothriochloa compressa (Hook.f.) Henrard (Andropogoneae: Poaceae). Int. J. Curr. Res. Biosci. Plant Biol., 9(1): 4244. doi: https://doi.org/10.20546/ijcrbp.2022.901.005
} 